\title{
P386: Bacterial contamination of health care provider's pagers in a tertiary care hospital
}

\author{
N Al Otaibi, A Alothman, K Mohajer, A Albadani, S Aljohani, A Al Mohanna \\ From 2nd International Conference on Prevention and Infection Control (ICPIC 2013) \\ Geneva, Switzerland. 25-28 June 2013
}

\section{Introduction}

In this era where nosocomial infections became a great threat to all tertiary care hospitals; we need to evaluate all modifiable risk factors for such morbidity. Medical instruments were thoughts to be involved in transmitting nosocomial isolates.

\section{Methods}

Health care providers (HCP) were chosen randomly in our tertiary care center, and had to fill a questionnaire and submit their bleep to be swabbed and serially numbered and sent to our microbiology lab to be cultured for 48 hours.

\section{Results}

120 pagers of 120 health care providers in our hospital were swabbed. The hundred twenty HCPs are classified as physician $(84.2 \%$, respiratory therapist $(5.0 \%)$, patient educator $(3 \%)$, nurses $(7.5 \%)$ and clinical pharmacist (0.8\%) $23.3 \%$ of physicians belong to Pediatric Department, while $19.2 \%$ from the Department of Medicine; $15.1 \%$ of physicians were from Department of Surgery. According from the questionnaire, $62.5 \%$ of the subjects never disinfect their pagers while $5 \%$ did disinfect their pagers daily. The microbiologic data showed that all pagers were contaminated by bacteria except two (1.7\%). The leading organism was coagulase-negative staphylococcus at $84.2 \%$; 2 pagers were contaminated by fungal elements $(1.7 \%)$; 1 pager was contaminated by methicillin-resistant staphylococcus aureus $(0.8 \%)$.

\section{Conclusion}

Pagers as well as other instruments used for patient's health can be contaminated by bacteria. A protocol

Medicine, King Abdulaziz Medical City, Riyadh, Saudi Arabia supposed to be made to disinfects, pagers, and all HCPs are supposed to be taught this protocol.

\section{Disclosure of interest}

None declared.

Published: 20 June 2013

doi:10.1186/2047-2994-2-S1-P386

Cite this article as: Al Otaibi et al:: P386: Bacterial contamination of

health care provider's pagers in a tertiary care hospital. Antimicrobial

Resistance and Infection Control 2013 2(Suppl 1):P386.
Submit your next manuscript to BioMed Central and take full advantage of:

- Convenient online submission

- Thorough peer review

- No space constraints or color figure charges

- Immediate publication on acceptance

- Inclusion in PubMed, CAS, Scopus and Google Scholar

- Research which is freely available for redistribution

Submit your manuscript at www.biomedcentral.com/submit
( Biomed Central

\section{Biomed Central}

(c) 2013 Al Otaibi et al; licensee BioMed Central Ltd. This is an Open Access article distributed under the terms of the Creative Commons Attribution License (http://creativecommons.org/licenses/by/2.0), which permits unrestricted use, distribution, and reproduction in any medium, provided the original work is properly cited. 